\title{
Molecular and radiocarbon constraints on sources and degradation of terrestrial organic carbon along the Kolyma paleoriver transect, East Siberian Sea
}

\author{
J. E. Vonk ${ }^{1}$, L. Sánchez-García ${ }^{1}$, I. Semiletov ${ }^{2,3}$, O. Dudarev ${ }^{2}$, T. Eglinton ${ }^{4}$, A. Andersson ${ }^{1}$, and Ö. Gustafsson ${ }^{1}$ \\ ${ }^{1}$ Department of Applied Environmental Science (ITM) and the Bert Bolin Climate Research Centre, Stockholm University, \\ Stockholm, Sweden \\ ${ }^{2}$ Pacific Oceanological Institute, Russian Academy of Sciences, Far Eastern Branch (FEBRAS), Vladivostok, Russia \\ ${ }^{3}$ International Arctic Research Center (IARC), University of Alaska Fairbanks, Fairbanks, USA \\ ${ }^{4}$ Department of Marine Chemistry and Geochemistry, Woods Hole Oceanographic Institution, Woods Hole, USA
}

Received: 17 June 2010 - Published in Biogeosciences Discuss.: 2 July 2010

Revised: 22 September 2010 - Accepted: 4 October 2010 - Published: 14 October 2010

\begin{abstract}
Climate warming in northeastern Siberia may induce thaw-mobilization of the organic carbon (OC) now held in permafrost. This study investigated the composition of terrestrial OC exported to Arctic coastal waters to both obtain a natural integration of terrestrial permafrost $\mathrm{OC}$ release and to further understand the fate of released carbon in the extensive Siberian Shelf Seas. Application of a variety of elemental, molecular and isotopic $\left(\delta^{13} \mathrm{C}\right.$ and $\left.\Delta^{14} \mathrm{C}\right)$ analyses of both surface water suspended particulate matter and underlying surface sediments along a $500 \mathrm{~km}$ transect from Kolyma River mouth to the mid-shelf of the East Siberian Sea yielded information on the sources, degradation status and transport processes of thaw-mobilized soil OC. A three end-member dual-carbon-isotopic mixing model was applied to deduce the relative contributions from riverine, coastal erosion and marine sources. The mixing model was solved numerically using Monte Carlo simulations to obtain a fair representation of the uncertainties of both end-member composition and the end results. Riverine OC contributions to sediment $\mathrm{OC}$ decrease with increasing distance offshore ( $35 \pm 15$ to $13 \pm 9 \%)$, whereas coastal erosion OC exhibits a constantly high contribution $(51 \pm 11$ to $60 \pm 12 \%)$ and marine OC increases offshore $(9 \pm 7$ to $36 \pm 10 \%)$. We attribute the remarkably strong imprint of OC from coastal erosion, extending up to $\sim 500 \mathrm{~km}$ from the coast, to efficient offshoreward transport in these shallow waters presumably through both the benthic
\end{abstract}

boundary layer and ice-rafting. There are also indications of simultaneous selective preservation of erosion OC compared to riverine $\mathrm{OC}$. Molecular degradation proxies and radiocarbon contents indicated a degraded but young $\left(\Delta^{14} \mathrm{C}\right.$ ca. $-60 \%$ or ca. $500{ }^{14} \mathrm{C}$ years) terrestrial OC pool in surface water particulate matter, underlain by a less degraded but old $\left(\Delta^{14} \mathrm{C}\right.$ ca. $-500 \%$ or ca. $5500{ }^{14} \mathrm{C}$ years $)$ terrestrial OC pool in bottom sediments. We suggest that the terrestrial OC fraction in surface water particulate matter is mainly derived from surface soil and recent vegetation fluvially released as buoyant organic-rich aggregates (e.g., humics), which are subjected to extensive processing during coastal transport. In contrast, terrestrial OC in the underlying sediments is postulated to originate predominantly from erosion of mineral-rich Pleistocene coasts (i.e., yedoma) and inland mineral soils. Sorptive association of this organic matter with mineral particles protects the OC from remineralization and also promotes rapid settling (ballasting) of the OC. Our findings corroborate recent studies by indicating that different Arctic surface soil OC pools exhibit distinguishing susceptibilities to degradation in coastal waters. Consequently, the general postulation of a positive feedback to global warming from degradation of permafrost carbon may be both attenuated (by reburial of one portion) and geographically displaced (degradation of released terrestrial permafrost OC far out over the Arctic shelf seas). 


\section{Introduction}

There are only a few mechanisms in the Earth system that can relocate substantial amounts of carbon from land and ocean into the atmosphere in response to a warming climate on a centennial timescale. Thaw-release of organic carbon (OC) from Arctic permafrost is postulated as one of the most powerful and vulnerable yet least understood such mechanisms (Gruber et al., 2004; McGuire et al., 2009; Schuur et al., 2008). Half of the global soil OC is stored in the top few meters of Arctic permafrost (Tarnocai et al., 2009). Approximately $25 \%$ of this soil-permafrost OC exists as so-called yedoma; organic-rich frozen loess deposits that accumulated during the Pleistocene (Zimov et al., 2006), predominantly in coastal northeastern Siberia (Fig. 1a). The widespread extent of Russian permafrost currently prevents significant exchange of this large and frozen OC reservoir with other, more active, carbon pools, including the atmosphere. However, ongoing climate warming, which is particularly pronounced in northeastern Siberia (Richter-Menge et al., 2006), is predicted to cause thaw-remobilization of part of the permafrost OC pool (e.g. Khvorostyanov et al., 2008; Schuur et al., 2008). Higher air temperatures are already causing detectable permafrost thawing (Sazonova et al., 2004; Chudinova et al., 2006; Romanovsky et al., 2007) and some models predict that the depth of seasonal thaw will increase with 15$50 \%$ by the year 2050 (e.g., Anisimov and Reneva, 2006).

Current studies estimate the input of OC to Arctic shelf seas to be equally large from coastal erosion and riverine OC export (Semiletov, 1999a; Rachold et al., 2000; Stein and Macdonald, 2004), with climate warming expected to increase the input of both. A reduction in Arctic Ocean ice cover will increase the wave fetch and storm frequency, leading to enhanced thermal degradation and erosion of the frozen yedoma-dominated coastline of northeastern Siberia (Fig. 1b). Furthermore, documented increases in the river discharge to the Arctic Ocean (Savelieva et al., 2000; Peterson et al., 2002, 2006) may accelerate the discharge of terrestrial organic matter from their extensive drainage basins. Thawing permafrost soil OC has been shown to manifest itself mostly in the age and amounts of particulate organic carbon (POC, Guo and Macdonald, 2006; Guo et al., 2007), and could increase riverine POC fluxes. Overall, amplified climate change in the Arctic has a strong potential to remobilize (old) soil OC pools into the active carbon cycle via degradation and remineralization to $\mathrm{CO}_{2}$ on land but also during enhanced export to the Arctic Ocean. The impact of the latter on carbon cycling in the marine environment, and on carbon-climate interactions would depend on its fate in coastal waters. In this study we seek to determine the fate of permafrost OC (degradation, reburial) discharged to the extensive coastal shelf environment of the East Siberian Arctic.

Coastal waters north of the Russian-Arctic are underlain by the world's largest continental shelf, with the East Siberian Sea (ESS) being its largest constituent shelf sea.
Despite its vastness, the carbon dynamics on the shallow ESS remain understudied. Here, we investigate the sources, degradation status and dispersion on the continental shelf of permafrost soil OC in this regime. The mixed input of terrestrial material from coastal erosion and river drainage basins to the southern ESS is assessed using molecular and bulk geochemical analyses on both surface water POC and surface sediment $\mathrm{OC}$ (SOC) to deduce the fate and processing of soil OC during transport through estuarine and shallow shelf environments.

Estimations of significant input of $\mathrm{OC}$ from eroding coastal yedoma into the ESS, roughly equaling riverine OC, is based on limited measurements of coastline retreat (Semiletov et al., 1999a; Rachold et al., 2000; Stein and Macdonald, 2004; Overduin et al., 2007) and thus subject to considerable uncertainties. These seemingly similar types of terrestrial carbon (i.e., from coastal erosion and rivers) could exhibit different potentials for positive feedback to climate warming, due to their difference in age (Pleistocene yedoma versus more recent river $\mathrm{OC}$ ) and potential susceptibilities toward degradation (e.g. van Dongen et al., 2008b; Vonk et al., 2010). This study addresses the relative input of coastal yedoma versus fluvial $\mathrm{OC}$ by apportioning the sources of $\mathrm{SOC}$ in recently deposited sediments with ${ }^{13} \mathrm{C}$ and ${ }^{14} \mathrm{C}$ isotopes. We also investigate the degradation dynamics of remobilized OC along a $\sim 500 \mathrm{~km}$ long transect from the mouth of the Kolyma River over the continental shelf. Analyses of both surface water suspended particulate matter (SPM) and bottom sediments allows examination of degradation processes during both horizontal transport (coast to mid-shelf) and vertical transport (surface water to bottom sediments).

\section{Materials and methods}

\subsection{Study area and sampling}

\subsubsection{Kolyma River}

The Kolyma River in northeastern Siberia drains a pristine high-Arctic catchment $\left(647 \times 10^{3} \mathrm{~km}^{2}\right.$; Stein and Macdonald, 2004) with a cold and dry climate (mean annual temperature $-11^{\circ} \mathrm{C}$, annual precipitation $260 \mathrm{~mm}$; Majhi and Yang, 2008). The complete catchment is located in the continuous permafrost zone (Romanovsky, 1993) with frozen ground depths up to $500 \mathrm{~m}$ and active layer depths between $0.2 \mathrm{~m}$ in the north and $1 \mathrm{~m}$ in the south (Uhlirrová et al., 2007). Pleistocene OC-rich yedoma deposits are abundant (Fig. 1a; Romanovsky, 1993; Zimov et al., 2006; Overduin et al., 2007). Lowland tundra vegetation is dominant along the coast whereas taiga forests (larch and spruce) and shrub tundra dominate in the rest of the basin (Huh et al., 1998; Majhi and Yang, 2008). The Kolyma and adjacent Indigirka drainage basins are colder, drier, and more mountainous than 
A

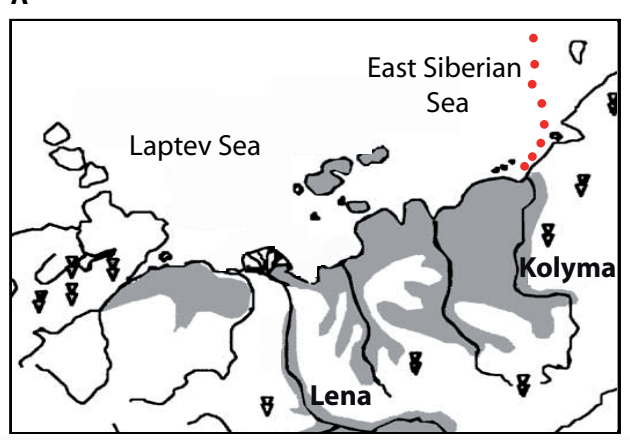

B

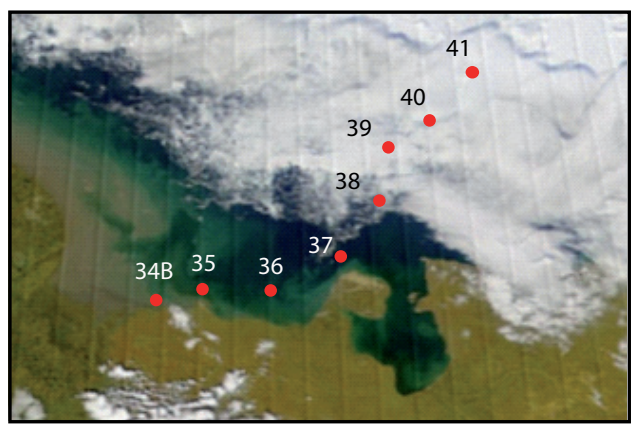

C

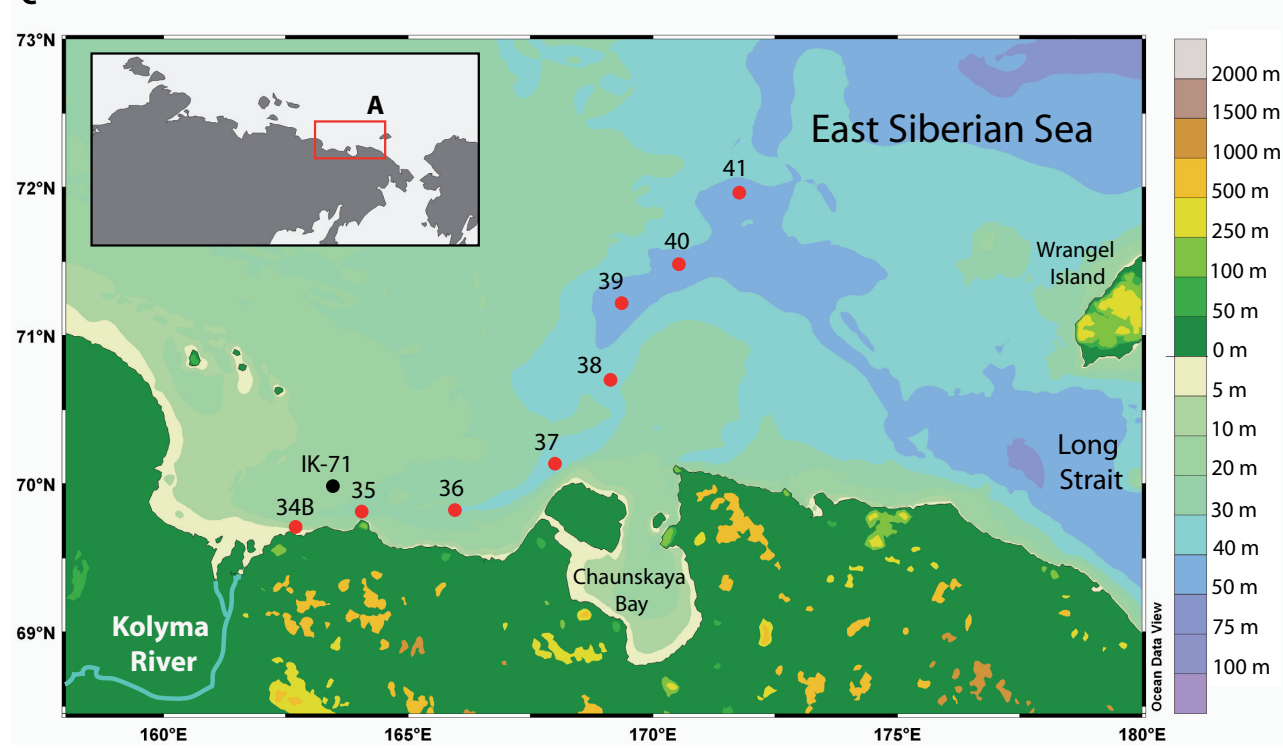

Fig. 1. (a) The distribution of Pleistocene yedoma (modified from Romanovsky, 1993) in northeastern Siberia: grey - areas of widespread yedoma; inverted triangles - yedoma spread in river valleys, deltas and lake plains. (b) A clear turbidity cloud can be seen from a satellite image, taken on 24 August 2000 (http://visibleearth.nasa.gov), likely from ongoing coastal erosion. (c) Map of the southern East Siberian Sea showing the location of the sampling stations (red circles) following the Kolyma paleoriver canyon. The black circle (IK-71) is a reference station from van Dongen et al. (2008a) where similar molecular analyses are reported.

the drainage basins of the large rivers in the central-western Russian Arctic (Ob, Yenisey and Lena).

As for most northern rivers, the Kolyma exhibits most of it annual discharge ( $114 \mathrm{~km}^{3} /$ year; Cooper et al., 2008) during freshet that reaches a maximum in late May/early June. Despite the construction of a dam in 1986, therewith reducing the peak flow and increasing winter flows (Woo et al., 2008), the annual hydrology still has a strong seasonal character. Approximately half of the fluvial total organic carbon (TOC) and $40 \%$ of the fluvial suspended matter flux into the ESS is delivered by the Kolyma River (Holmes et al., 2002; Stein and Macdonald, 2004). Average dissolved organic carbon (DOC) and POC concentrations are around 5.9 and $0.77 \mathrm{mg} / \mathrm{L}$ respectively (summer averages 2004 and 2005; McClelland et al., 2008), which is higher than for the other major Siberian-Arctic rivers.

\subsubsection{East Siberian Sea}

The ESS is the least explored but largest $\left(987 \times 10^{3} \mathrm{~km}^{2}\right)$ shelf sea in the Arctic Ocean (Stein and Macdonald, 2004). It is ice-covered $10-11$ months per year and very shallow, with half of its area having a water depth of less than $30 \mathrm{~m}$ (Vetrov et al., 2008). The ESS is often divided in two regimes (Viscosi-Shirley et al., 2003; Semiletov et al., 2005): a western region that is strongly influenced by coastal erosion and Lena River freshwater input, with surface and bottom salinities of 10.5-29.7 and 27.5-31.7, respectively; and an eastern region that experiences Pacific influence with surface and bottom salinities of 17.1-31.0 and 31.2-33.4, respectively (Semiletov et al., 2005). The long-term average position of the frontal zone separating these two regimes is around $160^{\circ} \mathrm{E}$ for the water column and $170^{\circ} \mathrm{E}$ for the sediments (Semiletov et al., 2005). Contributions of terrestrial organic 
matter to total SOC have been estimated based on bulk $\delta^{13} \mathrm{C}$ data to be up to $70-100 \%$ in the western and between 28 $70 \%$ in the eastern part (Semiletov et al., 2005). More than half of the terrestrial OC input into the ESS (Stein and Macdonald, 2004) is estimated to come from coastal erosion (Dudarev et al., 2006) based on calculations using coastal retreat rates (on average $\sim 3-5 \mathrm{~m} /$ year with maxima up to $30 \mathrm{~m} /$ year; Semiletov, 1999a, b; Rachold et al., 2000; Overduin et al., 2007). Holocene-average annual sedimentation rates are estimated to be around $0.15-0.20 \mathrm{~mm} / \mathrm{year}$ in the western ESS and around $0.06 \mathrm{~mm} / \mathrm{year}$ in the eastern ESS (Dudarev et al., 2006; Stein and Macdonald, 2004).

\subsubsection{Sampling}

Surface sediments and surface water SPM were collected from the ESS continental shelf between 3-5 September 2008 as part of the 50-day-long International Siberian Shelf Study (ISSS-08) onboard the H/V Yakob Smirnitskiy (Fig. 1 and Table 1). The samples were taken along a river mouth - midshelf transect following the Kolyma paleoriver canyon (water depths $\sim 10-50 \mathrm{~m}$ ). This submarine valley was formed during glacial periods when sea level was lower. Since inundation of the shelf, the canyon now serves as a natural sediment trap on the shallow ESS.

Surface sediments were collected at eight stations dispersed over $\sim 500 \mathrm{~km}$ (Fig. 1c) with a dual gravity corer (GEMAX, Kart Oy, Finland; modified at Stockholm University) and at stations YS-34B and YS-41 with a Van Veen grab sampler (due to sandy conditions and heavy weather, respectively). The top layers of the grab samples were retrieved with stainless steel spatulas, transferred into precleaned polyethylene containers and frozen until analysis. The collected sediment cores were sectioned into $1 \mathrm{~cm}$ slices using an extruder (Kart Oy, Finland), and similarly transferred to containers and immediately kept frozen at $-18^{\circ} \mathrm{C}$.

Surface water SPM was collected at five stations (YS-34B, $35,37,39,41$; Fig. 1c) by filtering surface seawater from the mixed layer through pre-combusted $\left(12 \mathrm{~h}, 450^{\circ} \mathrm{C}\right) 293 \mathrm{~mm}$ glass fiber filters (GF/F, $0.7 \mu \mathrm{m}$, Whatman). At stations YS34B and YS-39 the water was retrieved onboard by deploying a submersible pump (model AN19, Debe Pumpar AB, Sweden) connected with reinforced silicon and PVC tubing to the filtration set-up as detailed earlier (Sobek et al., 2004; Gustafsson et al., 2006). At all other stations, the ship's specially-constructed sea water intake system was employed. This consisted of two parallel-coupled pumps (Aquaria Selfpriming pump, Model ASS-80) that transferred water from below the ship's hull through steel pipes and silicon tubing into a $300 \mathrm{~L}$ overflow barrel at $30 \mathrm{~L} / \mathrm{min}$, leading onwards into a deckboard seawater distribution network. This seawater distribution network and the $293 \mathrm{~mm} \mathrm{GF/F} \mathrm{filtra-}$ tion system were constructed of stainless steel filter holders and couplings connected to reinforced PVC tubing and was thoroughly pre-rinsed before sample collection. The
Table 1. Sampling locations and organic carbon content of samples recovered along the Kolyma paleoriver transect.

\begin{tabular}{|c|c|c|c|c|c|c|}
\hline \multirow[t]{2}{*}{ Sample } & \multicolumn{2}{|c|}{ Coordinates } & \multirow{2}{*}{$\begin{array}{l}\text { Distance to } \\
\text { river mouth }{ }^{\mathrm{a}} \\
(\mathrm{km})\end{array}$} & \multirow{2}{*}{$\begin{array}{l}\text { Sampling } \\
\text { depth } \\
\text { (m) }\end{array}$} & \multirow[t]{2}{*}{ Salinity } & \multirow{2}{*}{$\begin{array}{c}\text { OC } \\
\mathrm{mg} / \mathrm{gdv}\end{array}$} \\
\hline & $\mathrm{N}$ & $\mathrm{E}$ & & & & \\
\hline \multicolumn{7}{|c|}{ surface sediments } \\
\hline YS-34B & 69.71 & 162.69 & 46 & 10 & 29.9 & 11.2 \\
\hline YS-35 & 69.82 & 164.06 & 100 & 31 & 30.6 & 12.2 \\
\hline YS-36 & 69.82 & 166.00 & 174 & 32 & 30.8 & 8.02 \\
\hline YS-37 & 70.13 & 168.01 & 258 & 42 & 31.1 & 9.40 \\
\hline YS-38 & 70.70 & 169.13 & 334 & 36 & 31.6 & 10.0 \\
\hline YS-39 & 71.22 & 169.37 & 392 & 44 & 32.4 & 12.3 \\
\hline YS-40 & 71.48 & 170.55 & 443 & 49 & 32.9 & 13.6 \\
\hline YS-41 & 71.97 & 171.79 & 513 & 43 & 33.2 & 13.2 \\
\hline \multicolumn{6}{|c|}{ surface water suspended particles } & $\mu \mathrm{g} / \mathrm{L}$ \\
\hline YS-34B & 69.71 & 162.69 & 46 & 1 & 17.8 & 197 \\
\hline YS-35 & 69.82 & 164.06 & 100 & 4 & 29.4 & 313 \\
\hline YS $-36^{\mathrm{b}}$ & 69.82 & 166.00 & 174 & 2 & 28.4 & 81.2 \\
\hline YS-37 & 70.13 & 168.01 & 258 & 4 & 27.5 & 71.3 \\
\hline YS $-38^{b}$ & 70.70 & 169.13 & 334 & 4 & 27.6 & 58.9 \\
\hline YS-39 & 71.22 & 169.37 & 392 & 4 & 27.6 & 54.5 \\
\hline YS-41 & 71.97 & 171.79 & 513 & 4 & 27.7 & 63.4 \\
\hline
\end{tabular}

a Measured along the paleoriver transect, river mouth defined as $69.65^{\circ} \mathrm{N}, 161.50^{\circ} \mathrm{E}$. b OC content on POC from YS-36 and YS-38 from Sánchez-García et al. (2010a).

GF/F filtration system was placed inside a laboratory container on the fore deck to minimize influence from ship's exhaust. Volumes were measured with in-line electronic flow meters and back pressures were monitored and kept below 1 bar to avoid cell lyzing and clogging effects. Excess sea water was drained and filters were cleanly transferred to and stored in pre-combusted aluminum envelopes and kept frozen at $-18^{\circ} \mathrm{C}$ until analysis.

\subsection{Methods}

\subsubsection{Bulk elemental and isotope analyses}

From each station, $9-13 \mathrm{mg}$ dried $\left(60^{\circ} \mathrm{C}, 24 \mathrm{~h}\right)$, ground and homogenized sediment was weighed into pre-combusted silver capsules $(5 \times 9 \mathrm{~mm}$, Säntis Analytical AG, Teufen, Switzerland). Samples were acidified in situ in Ag capsules with $1 \mathrm{M} \mathrm{HCl}$ to remove carbonates and dried overnight at $60^{\circ} \mathrm{C}$. Total SOC content and its $\delta^{13} \mathrm{C}$ signal were measured on triplicate samples using an isotope ratio mass spectrometer (Europe Hydra 20/20, University of California, Davis Stable Isotope Facility, USA). Subsamples were punched out from the GF/F filters (12-14 punches of $4 \mathrm{~mm}$ diameter), and similarly acidified and dried in pre-combusted Ag capsules $(5 \times 12 \mathrm{~mm})$. The POC and its $\delta^{13} \mathrm{C}$ content were measured at Stockholm University (Department of Geological Sciences, Sweden) with a Carlo Erba NC2500 elemental analyzer connected via a split interface to a Finnigan MAT Delta Plus mass spectrometer. A second set of punched out and similarly acidified GF/F filters was sent to the US National Ocean Sciences Accelerator Mass Spectrometry 
(NOSAMS) facility of the Woods Hole Oceanographic Institution (WHOI, Woods Hole, USA) for $\Delta^{14} \mathrm{C}$ analyses. Freeze-dried untreated subsamples of the surface sediments were also sent to NOSAMS where they were acidified before bulk organic $\Delta^{14} \mathrm{C}$ analysis.

\subsubsection{Lipid extraction and purification}

The freeze-dried SPM and ground surface sediment samples were Soxhlet extracted $(24 \mathrm{~h})$ with dichloromethane/methanol (DCM/MeOH, 2:1 v/v). Internal standards $\left(\mathrm{D}_{50}\right.$-tetracosane, $\mathrm{D}_{39}$-eicosanoic acid and 2-hexadecanol) were added to aliquots of the concentrated extracts. The extracts were further cleaned, separated into nonpolar, acid and polar fractions with Bond-Elut ${ }^{\circledR}$ (bonded phase $\mathrm{NH}_{2}$, Varian, The Netherlands) and $\mathrm{Al}_{2} \mathrm{O}_{3}$ column chromatography and derivatized as described in Vonk et al. (2008). Laboratory blanks revealed a $\mathrm{C}_{16}$ and $\mathrm{C}_{18} n$-alkanoic acid contamination, most likely originating from the Bond-Elut ${ }^{\circledR}$ columns (Russell and Werne, 2007). No significant contamination occurred of any of the target analytes. Recoveries were on average $84 \pm 25 \%$ (one standard deviation; $n=16$ ).

\subsubsection{Instrumental analyses}

The nonpolar, acid and polar fractions were analyzed using gas chromatography-mass spectrometry (GC-MS) with an 8060 gas chromatograph interfaced to a MD 800 mass spectrometer (both Fisons PLC, Ipswich, Suffolk, UK) operating with electron ionization at $70 \mathrm{eV}$ and scanning from $\mathrm{m} / \mathrm{z} 50$ to 600 . The analytes were injected $(1 \mu \mathrm{l})$ oncolumn and separated on a PTE-5 (Supelco Inc, Bellefonte, Pennsylvania, USA) capillary column (5\%-diphenyldimethyl-polysiloxane, length $30 \mathrm{~m}$, i.d. $0.25 \mathrm{~mm}$, film thickness $0.25 \mu \mathrm{m}$ ). The transfer line to the mass spectrometer was kept at $300^{\circ} \mathrm{C}$ and the ion source at $240^{\circ} \mathrm{C}$. Temperature program settings of the GC can be found in Vonk et al. (2008).

\subsubsection{Monte Carlo simulations}

This study addresses the relative input of three different sources (i.e. riverine, erosion and marine OC) to the SOC in recently deposited sediments by applying a three endmember mixing model with two carbon isotopic signals for each end-member $\left({ }^{13} \mathrm{C}\right.$ and $\left.{ }^{14} \mathrm{C}\right)$. We have applied a random sampling (Monte Carlo, MC) computer simulation strategy to incorporate the effect of the spread in end-member values on the quantitative source apportionment. The simulations were based on the assumption that the end-member values $\left(\Delta^{14} \mathrm{C}_{\text {riverine }}, \Delta{ }^{14} \mathrm{C}_{\text {erosion }}, \Delta{ }^{14} \mathrm{C}_{\text {marine }}, \delta^{13} \mathrm{C}_{\text {riverine }}\right.$, $\delta^{13} C_{\text {erosion }}$ and $\delta^{13} C_{\text {marine }}$; see Sect. 3.3) could be represented by a normal distribution, where the mean and standard deviation are estimated from ISSS-08 data and from the literature. The calculations were performed using ran- dom sampling from these normal distributions, while simultaneously fulfilling Eqs. (1) to (3) (Sect. 3.3). By repeating the random sampling (400000 times) and sorting the results in histograms (256 bins), distributions (as probability density functions) of the fractions $f_{\text {riverine }}, f_{\text {erosion }}$ and $f_{\text {marine }}$ were obtained (Fig. 3a and b). These distributions were used to calculate the mean and the standard deviation as summarized in Table 3. Details on repeatability, predictability and end-member ranges are discussed in Supplement Text S1. The MC calculations were performed in Matlab version 7.9.0 (The MathWorks, Natick, USA).

\section{Results and discussion}

\subsection{Marine and terrestrial sources of organic matter}

The Kolyma paleoriver transect shows a clear imprint of terrestrial OC in both the surface water SPM and the underlying surface sediments. The OC contents in the sediments were between 8.0 and $14 \mathrm{mg} / \mathrm{gdw}$ (Table 1; Fig. 2a), which are in the same range as reported previously (Stein and Macdonald, 2004; Semiletov et al., 2005; Vetrov et al., 2008). For surface POC, concentrations were between $200-300 \mu \mathrm{g} / \mathrm{L}$ near the coast, rapidly decreasing to around $60 \mu \mathrm{g} / \mathrm{L}$ further offshore (Table 1; Fig. 2a). There are no published reports of suspended POC concentration (nor molecular or isotopic composition of POC) in the ESS to compare with. The Kolyma River POC concentrations are between 400 and $600 \mu \mathrm{g} / \mathrm{L}$ this time of year (McClelland et al., 2008), but apart from the river mouth station (YS-34B), direct river plume influence was only minimal during our sampling campaign as illustrated by high salinities (Table 1). Stable carbon isotope signatures (Table 2) increased from typically terrestrial $\delta^{13} \mathrm{C}$ values in the inner part of the transect (sedimentSOC of $-27.3 \%$, surface-POC of $-29.1 \%$ o) to a more even contribution from terrestrial and marine sources at the outer transect/mid-shelf region (sediment $-23.9 \%$ o, POC between -23.3 and $-26.4 \%$; Fig. $2 b$ ).

Molecular markers support a strong terrestrial influence for sediments but give a more ambiguous picture for surface water SPM. The terrestrial plant predominance in SOC was illustrated by the abundant presence of high-molecular weight (HMW) $n$-alkanes and $n$-alkanoic acids (Table 2 and Supplement Tables S2 and S3) originating from leaf waxes in higher plants (e.g. Eglinton and Hamilton, 1967). Carbon preference indices (CPI) were high in sediments for $n$-alkanes (3.7-7.6; Table 2; Fig. 4b) and $n$-alkanoic acids (3.5-4.2; Table 2). Living plants commonly have values $>5$ (Rieley et al., 1991) and approach 1 with increasing thermal maturity. Suspended matter showed similar CPI values for $n$-alkanoic acids (3.7-7.9) but had lower $n$-alkane CPIs (0.86-2.5; Table 2). Apparently, there is a source of highly degraded $n$-alkanes present in the mixed layer POC. The ratio of terrestrial HMW ( $\left.>\mathrm{C}_{20}\right) n$-alkanes to 

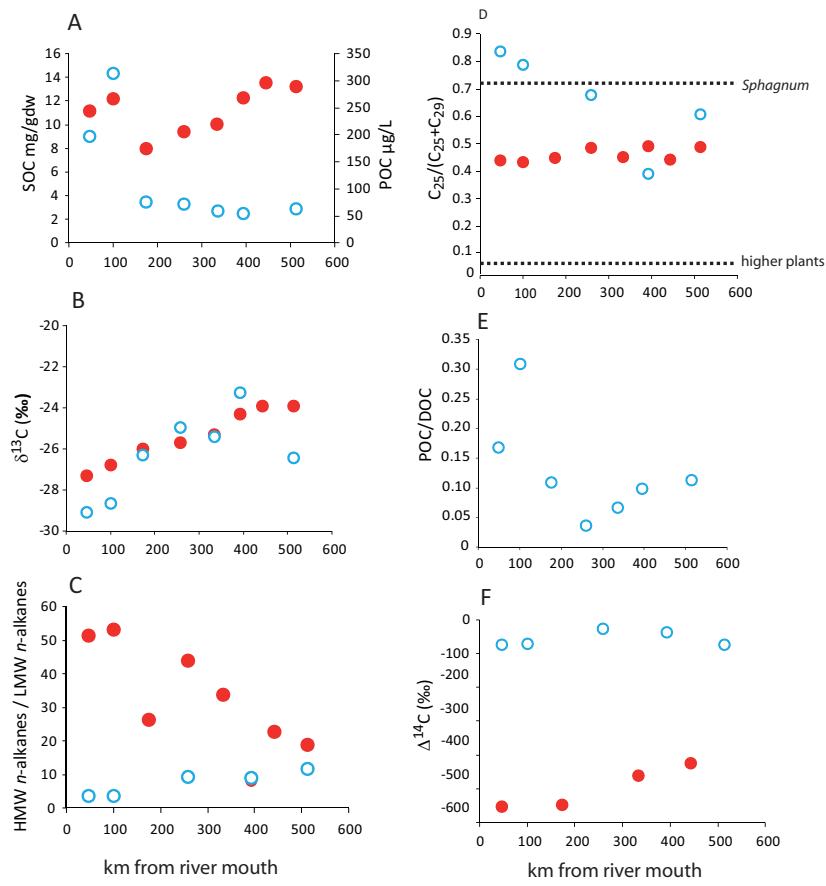

Fig. 2. Bulk and molecular properties showing the sources and origin of terrestrial organic carbon in sediment OC (SOC; red closed symbols) and surface water particulate OC (POC; blue open symbols) with distance from the river mouth: (a) organic carbon contents (SOC in $\mathrm{mg} / \mathrm{gdw}$ and POC in $\mu \mathrm{g} / \mathrm{L}$ ), (b) stable carbon signatures $\left(\delta^{13} \mathrm{C}\right.$ in \%o), (c) high-molecular weight (HMW) $n$ alkane/low-molecular weight (LMW) $n$-alkane ratio, (d) $n$-alkane ratio $\mathrm{C}_{25} /\left(\mathrm{C}_{25}+\mathrm{C}_{29}\right)$, (e) $\mathrm{POC} / \mathrm{DOC}$ ratio for surface water column (Sánchez-García et al., 2010a) and (f) $\Delta^{14} \mathrm{C}$ values (\%o).

marine low-molecular weight (LMW; $\left.\mathrm{C}_{17}+\mathrm{C}_{19}\right) n$-alkanes (Fig. 2c) also suggests an overwhelmingly terrestrial source for SOC throughout the entire transect. In sharp contrast, the HMW/LMW $n$-alkane ratio in POC suggests contribution also from marine-planktonic sources. The dichotomy is largest for the inner portion of the transect, whereas this ratio approaches values around 10-20 for both SPM and sediments for the most offshore stations of the transect (Fig. 2c).

Marine sterols such as asterosterol, trans-22dehydrocholesterol and brassicasterol (Supplement Table S4) are more abundant in SPM than in surface sediments. However, sterols with a predominantly higher plant source (campesterol, stigmasterol and $\beta$-sitosterol; Yunker et al., 1995) are also more abundant in SPM than in surface sediments (Supplement Table S4), as was found in an earlier study (Vonk et al., 2008). These sterols have also been reported in previous studies on Siberian and Canadian Arctic coastal sediments (e.g. Yunker et al., 1995, 2005; van Dongen et al., 2008a). The weaker sterol imprint in sediments relative to e.g. long-chain $n$-alkanes is likely caused by more efficient degradation during both water column scavenging and lateral bottom transport. In combination with their weaker source-specific character sterols are thus less useful as tracers of recalcitrant terrestrial $\mathrm{OC}$ in the coastal system. Taken together, the depleted $\delta^{13} \mathrm{C}$ values and molecular fingerprints suggest that there is a dominant terrestrial signature of the organic matter dispersed across this transect in the central ESS.

\subsection{Origin of terrestrial organic matter}

It is believed that both fluvial discharge and coastal erosion are important sources of terrestrial OC to the ESS, with large uncertainties regarding the magnitude of the latter. We infer an important contribution of peatland/wetland-derived material from high $\mathrm{C}_{25} /\left(\mathrm{C}_{25}+\mathrm{C}_{29}\right)$ ratios in the surface sediments (around 0.45; Fig. 2d) that indicate the presence of terrestrial OC derived from Sphagnum or similar plants (Vonk and Gustafsson, 2009). This material most likely originates from the tundra lowlands along the coast where peatlands are abundant. Van Dongen et al. (2008a) reported a similar value (0.41) for a site off the Kolyma River mouth. While these values indicate a substantial contribution from Sphagnum, these values are slightly lower than the proxy value reported for the western Russian Arctic River Ob (0.52, recalculated from data in van Dongen et al., 2008a). This is likely due to the fact that this river drains the extensive West Siberian peatlands (Kremenetski et al., 2003). The $\mathrm{C}_{25} /\left(\mathrm{C}_{25}+\mathrm{C}_{29}\right)$ ratios in surface POC are as high as 0.84 close to the river mouth, nearly twice as high as in the sediments, and higher than the Sphagnum end-member in (sub-)Arctic Scandinavia (0.72; Vonk and Gustafsson, 2009). Possibly, Sphagnum or other moss or wetland species in the Kolyma basin have an even higher $\mathrm{C}_{25} n$-alkane predominance, giving rise to higher ratios in the POC released in late summer. Erosion of coastal yedoma could also contribute to the high $\mathrm{C}_{25} /\left(\mathrm{C}_{25}+\mathrm{C}_{29}\right)$ ratios near the coast. Preliminary results from a molecular study on several eroding coastal yedoma profiles showed $\mathrm{C}_{25} /\left(\mathrm{C}_{25}+\mathrm{C}_{29}\right)$ ratios to be between 0.3 and 0.95 (southern Laptev Sea, Sánchez-García et al., 2010b).

Another study by Sánchez-García et al. (2010a) in the complete Laptev Sea and ESS showed that coastally eroded organic matter tends to settle close to land as demonstrated by sharp decreasing POC/DOC ratios offshore. Following the Kolyma paleoriver transect, the surface POC/DOC also shows a clear decrease with increasing distance offshore (from POC/DOC ratios of $0.17-0.31$ to $0.037-0.10$; Fig. 2e), suggesting a strong impact of coastal erosion close to land. However, average Kolyma POC/DOC ratios in $\mathrm{Au}-$ gust/September are around 0.14 (between 0.07 and 0.21 for 2003, 2004 and 2005; McClelland et al., 2008), so one cannot completely exclude riverine $\mathrm{OC}$ to contribute to a high $\mathrm{POC} / \mathrm{DOC}$ ratio in this region. We propose a dual-carbonisotope three end-member OC mixing model (riverine, erosional and marine) to estimate the relative contribution of these sources to the SOC. 
Table 2. Molecular concentrations (in $\mu \mathrm{g} / \mathrm{gOC}$ ) of terrestrial lipid biomarkers and carbon isotopic compositions in surface sediments and surface water suspended particles along the Kolyma paleoriver transect. Concentrations of all analyzed molecular biomarkers can be found in the Supplement Tables S2-S4. The $\delta^{13} \mathrm{C}$ and $\Delta^{14} \mathrm{C}$ ratios are given in per mil measured relative to VPDB and NBS Oxalic Acid I, respectively.

\begin{tabular}{|c|c|c|c|c|c|c|c|c|}
\hline & YS-34B & YS-35 & YS-36 & YS-37 & YS-38 & YS-39 & YS-40 & YS-41 \\
\hline \multicolumn{9}{|c|}{ surface sediments } \\
\hline$\delta^{13} \mathrm{C}$ & -27.3 & -26.8 & -26.0 & -25.7 & -25.3 & -24.3 & -23.9 & -23.9 \\
\hline$\Delta^{14} \mathrm{C}$ & -553 & - & -546 & - & -460 & - & -424 & - \\
\hline \multicolumn{9}{|l|}{$n$-alkanes } \\
\hline $\mathrm{HMW}^{\mathrm{a}} n$-alkanes & 1170 & 639 & 2820 & 1370 & 948 & 747 & 675 & 628 \\
\hline $\mathrm{C}_{25} /\left(\mathrm{C}_{25}+\mathrm{C}_{29}\right)$ & 0.44 & 0.43 & 0.45 & 0.49 & 0.45 & 0.49 & 0.44 & 0.49 \\
\hline HMW/LMW ${ }^{\mathrm{b}} n$-alkanes & 51.2 & 53.1 & 26.3 & 43.9 & 33.7 & 8.21 & 22.7 & 19.0 \\
\hline CPI $21-31^{\mathrm{c}}$ & 7.56 & 4.69 & 4.49 & 4.39 & 5.20 & 3.76 & 4.15 & 3.70 \\
\hline \multicolumn{9}{|l|}{$n$-alkanoic acids } \\
\hline HMW $^{\mathrm{a}} n$-alkanoic acids & 3690 & 3750 & 2050 & 5370 & 2740 & 1320 & 1990 & 1840 \\
\hline CPI $20-30^{\mathrm{c}}$ & 3.70 & 3.45 & 3.59 & 4.20 & 3.85 & 4.03 & 3.85 & 3.95 \\
\hline
\end{tabular}

\begin{tabular}{|c|c|c|c|c|c|c|c|c|}
\hline \multicolumn{9}{|c|}{ surface water suspended particles } \\
\hline$\delta^{13} \mathrm{C}^{\mathrm{d}}$ & -29.1 & -28.7 & -26.3 & -25.0 & -25.3 & -23.3 & - & -26.4 \\
\hline$\Delta^{14} \mathrm{C}$ & -75.0 & -70.7 & - & -27.9 & - & -37.4 & - & -73.7 \\
\hline \multicolumn{9}{|l|}{$n$-alkanes } \\
\hline $\mathrm{HMW}^{\mathrm{a}} n$-alkanes & 517 & 351 & - & 210 & - & 149 & - & 402 \\
\hline $\mathrm{C}_{25} /\left(\mathrm{C}_{25}+\mathrm{C}_{29}\right)$ & 0.835 & 0.789 & - & 0.678 & - & 0.391 & - & 0.608 \\
\hline HMW/LMW $n$-alkanes & 3.60 & 3.62 & - & 9.46 & - & 9.14 & - & 11.7 \\
\hline CPI $21-31^{\mathrm{c}}$ & 2.46 & 1.35 & - & 0.861 & - & 2.22 & - & 2.22 \\
\hline \multicolumn{9}{|l|}{$n$-alkanoic acids } \\
\hline $\mathrm{HMW}^{\mathrm{a}} n$-alkanoic acids & 570 & 366 & - & 203 & - & 125 & - & 809 \\
\hline CPI $20-30^{\mathrm{c}}$ & 4.41 & 3.70 & - & 7.90 & - & 6.61 & - & 5.43 \\
\hline
\end{tabular}

\footnotetext{
${ }^{\text {a }}$ HMW is high-molecular weight, sum of $\mathrm{C}_{20}-\mathrm{C}_{32}$ for $n$-alkanes and $\mathrm{C}_{20}-\mathrm{C}_{30}$ for $n$-alkanoic acids.

${ }^{\mathrm{b}} \mathrm{LMW}$ is low-molecular weight, sum of the concentrations of $\mathrm{C}_{17}-\mathrm{C}_{19}$ for $n$-alkanes.

${ }^{\mathrm{c}}$ calculated $\mathrm{CPI}_{i-n}$, carbon preference index $=1 / 2 \Sigma\left(X_{i}+X_{i+2}+\ldots+X_{n}\right) / \Sigma\left(X_{i-1}+X_{i+1}+\ldots+X_{n-1}\right)+{ }^{1} / 2 \Sigma\left(X_{i}+X_{i+2}+\ldots+X_{n}\right) / \Sigma\left(X_{i+1}+X_{i+3}+\ldots+X_{n+1}\right)$,

where $X$ is concentration.

d $\delta^{13} \mathrm{C}$ data on POC from YS-36 and YS-38 from Sánchez-García et al. (2010a).
}

\subsection{Quantitative source apportionment of sedimentary organic matter}

A three end-member isotopic approach was applied to elucidate the relative contributions of $\mathrm{OC}$ from riverine discharge, coastal erosion and marine productivity along the paleoriver transect. A key uncertainty is the magnitude of erosional OC input. The erosion-OC has never been specifically studied from the receiving ocean side, but its input has thus far only been roughly estimated based on coastline retreat and OC content of the yedoma (e.g. Semiletov, 1999a; Rachold et al., 2000; Stein and Macdonald, 2004). Better estimates are needed to quantify the input of Pleistocene OC into the ESS coastal system. Since both coastal yedoma OC and riverine $\mathrm{OC}$ are terrestrial in origin, their molecular and bulk characteristics are similar (Sect. 3.1). However, an obvious dif- ference is the average age of these OC pools. Yedoma OC originates in Pleistocene times and has been freeze-locked in permafrost ever since, while riverine OC reflects a mixture of younger sources (e.g. Neff et al., 2006) from annual active layer thaw to deeper (mineral) soils and peat deposits formed since the early Holocene (MacDonald et al., 2006). OC ${ }^{14} \mathrm{C}$ signatures should therefore be useful for estimating the relative contributions from riverine, erosion, and marine sources. Bulk $\Delta^{14} \mathrm{C}$ values in surface sediments were between $-553 \%$ near the river mouth, gradually increasing to $-424 \%$ at $440 \mathrm{~km}$ from the shore (Fig. 2f; Table 2). This corresponds to average ${ }^{14} \mathrm{C}$ ages of approximately 6500 to $4500{ }^{14} \mathrm{C}$ years, respectively. These values are in the same range as those measured for SOC in other Russian Arctic estuaries ( $-279 \%$ o to $-805 \%$; Guo et al., 2004; van Dongen et al., 2008a). Combining with stable carbon isotope 
end-members for the same three sources, yields the following equations:

$$
\begin{aligned}
f_{\text {riverine }}+ & f_{\text {erosion }}+f_{\text {marine }}=1 \\
\delta^{13} \mathrm{C}_{\text {sample }} & =f_{\text {riverine }} \delta^{13} \mathrm{C}_{\text {riverine }}+f_{\text {erosion }} \delta^{13} \mathrm{C}_{\text {erosion }} \\
& +f_{\text {marine }} \delta^{13} \mathrm{C}_{\text {marine }} \\
\Delta^{14} \mathrm{C}_{\text {sample }} & =f_{\text {riverine }} \Delta{ }^{14} \mathrm{C}_{\text {riverine }}+f_{\text {erosion }} \Delta{ }^{14} \mathrm{C}_{\text {erosion }} \\
& +f_{\text {marine }} \Delta{ }^{14} \mathrm{C}_{\text {marine }}
\end{aligned}
$$

Where $f_{\text {riverine, }}, f_{\text {erosion }}$ and $f_{\text {marine }}$ are the fractions of riverine, erosion and marine OC contribution to the samples, respectively.

Riverine $\delta^{13} \mathrm{C}$ of Kolyma River POC, reported in McClelland et al. (2008), show a mean value of $-29.3 \%$ (standard deviation $1.7 \%$; $n=15$ ) for data collected during June to September from 2003 to 2006, when the bulk of the terrestrial OC is released. As far as we know, no previous $\Delta^{14} \mathrm{C}$ values have been reported for Kolyma River POC. Unpublished results from the Siberian Arctic Lena River give $\Delta^{14} \mathrm{C}$ values of $-220 \%$ o to $-350 \%$ o for riverine bulk POC (mean $-296 \%$, standard deviation $68 \%$ ), whereas the Yukon and Sag Rivers in Alaska exhibit $\Delta^{14} \mathrm{C}$ values between $-250 \%$ o and $-560 \%$ (Guo and Macdonald, 2006; Guo et al., 2007). Somewhat lower values are reported for the Mackenzie River (Goñi et al., 2005; Guo et al., 2007) but this is likely due to the erosion of petroleum source rocks in its drainage basin (Goñi et al., 2005). The drainage basins of Lena and Kolyma River, and the character of transported POC, show similarities in permafrost coverage, soil OC and yedoma content and vegetation (Fig. 1a; Zimov et al., 2006; van Dongen et al., 2008a; Tarnocai et al., 2009). We have therefore chosen to use the average Lena River $\Delta^{14} \mathrm{C}$ POC value $(-296 \%$ ) as central riverine value in our end-member mixing model. We will use $-29.3 \%$ as central riverine $\mathrm{POC}$ value for $\delta^{13} \mathrm{C}$. These riverine end-members will include a fraction of old OC from river bank erosion. However, these inputs are likely small in the Kolyma drainage basin compared to the erosion OC input from the East Siberian coast, where thermal degradation is enhanced by the mechanical energy of tides, waves and storms.

Studies on coastal yedoma OC in the Laptev Sea and ESS report $\delta^{13} \mathrm{C}$ end-member values between $-22 \%$ and $-29 \%$ (Schirrmeister et al., 2002; Stein and Macdonald, 2004; Dutta et al., 2006; Sánchez-García et al., 2010b) with most of the measurements in the range of $-24 \%$ o to $-27 \%$. Generally, the ratios become more enriched with lower OC contents, i.e. further stage of decomposition. Radiocarbon dating on bulk soil OC in eroding coasts of the Laptev Sea and ESS show values between $-400 \%$ and $-1000 \%$ (Dutta et al., 2006; Sánchez-García et al., 2010b) with most of the observations towards the more depleted part of the range $(-650 \%$ o to $-950 \%$ ). For the three end-member mixing model we have selected the values of $-25.8 \%$ (standard deviation $1.71 \%$ ) and $-788 \%$ (standard deviation $201 \%$ ) for $\delta^{13} \mathrm{C}$ and $\Delta^{14} \mathrm{C}$, respectively (mean values for 26 data points on erosion profiles in Kolyma delta, Dutta et al., 2006; and Laptev Sea, Sánchez-García et al., 2010b).

Marine $\delta{ }^{13} \mathrm{C}$ end-members in high latitude areas can range between $-18 \%$ and $-30 \%$ o (e.g. Rau et al., 1982; Goericke and Fry, 1994; Gustafsson et al., 2005) but are commonly chosen to be between $-20 \%$ and $-22 \%$ o (e.g. Meyers, 1997; Semiletov et al., 2005). Values for $\Delta^{14}$ C-DIC are not known for surface waters in the ESS, but measurements in the nearby northern Pacific Ocean (Key et al., 2004) range between $-10 \%$ and $60 \%$. For the Canadian Arctic shelf, limited measurements show ${ }^{14} \mathrm{C}$-DIC values around $-50 \%$ o (Östlund, Possnert and Swift, 1987; Schlosser et al., 1994b). Considering the direct influence of Pacific waters on the ESS (Semiletov et al., 2005) we believe the assumption of using $\Delta^{14} \mathrm{C}$ DIC data from the northern Pacific to be a reasonable one. The central values of $-21 \%$ of $\delta^{13} \mathrm{C}$ and $25 \%$ or $\Delta{ }^{14} \mathrm{C}$ were used as our marine end-members in the isotopic mixing model.

The three end-member mixing model resulted in mean values for the relative fractions of $13-35 \%$ riverine, 51$60 \%$ coastal erosion and $9-36 \%$ marine OC in the surface sediments along the paleoriver transect (Fig. $3 \mathrm{c}$ and Table 3). The end-members values are subjected to some variability due to our incomplete knowledge of the Arctic system. However, the use of an MC simulation method that includes the standard deviations of the chosen end-members will account for some of this uncertainty in the source apportionment. The MC simulations (described in detail in the method section and in Supplement Text S1) provided statistical means (i.e. standard deviation) for the sensitivity of our calculation, as reported in Table 3, and shown in Fig. 3a and b. Another important issue that is addressed by this methodology is the difference in bias between different end-members, e.g. the standard deviation in $\Delta^{14} \mathrm{C}$ end-member values is $201 \%$ of erosion as compared to $68 \%$ and $25 \%$ or riverine and marine sources respectively. These differences in bias affect the position, width and asymmetry (shape) of the calculated distribution functions (Fig. 3a and b). The relative proportion of marine OC increases offshore while the riverine OC contribution decreases. Notably, the relative proportion of yedoma $\mathrm{OC}$ is the highest and remains fairly constant along the paleoriver transect. Stein and Macdonald (2004) estimated the TOC fluxes into the ESS to be $11 \%, 10 \%$ and $79 \%$ for riverine, coastal erosion and marine OC, respectively. The lower fraction of marine OC found in the surface sediment may be explained by the more labile character of marine OC compared to terrestrial OC (Hedges et al., 1997; Hedges and Oades, 1997). Marine OC is likely subjected to extensive remineralization prior to deposition and burial (up to 90\%; Stein and Macdonald, 2004). Semiletov et al. (2005) calculated a relative terrestrial contribution (i.e. sum of riverine and coastal erosion) of $70-100 \%$ for SOC 
A
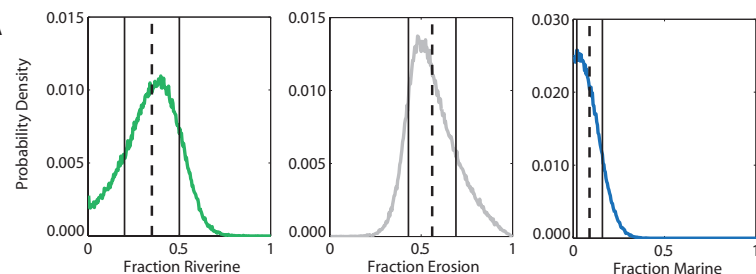

B
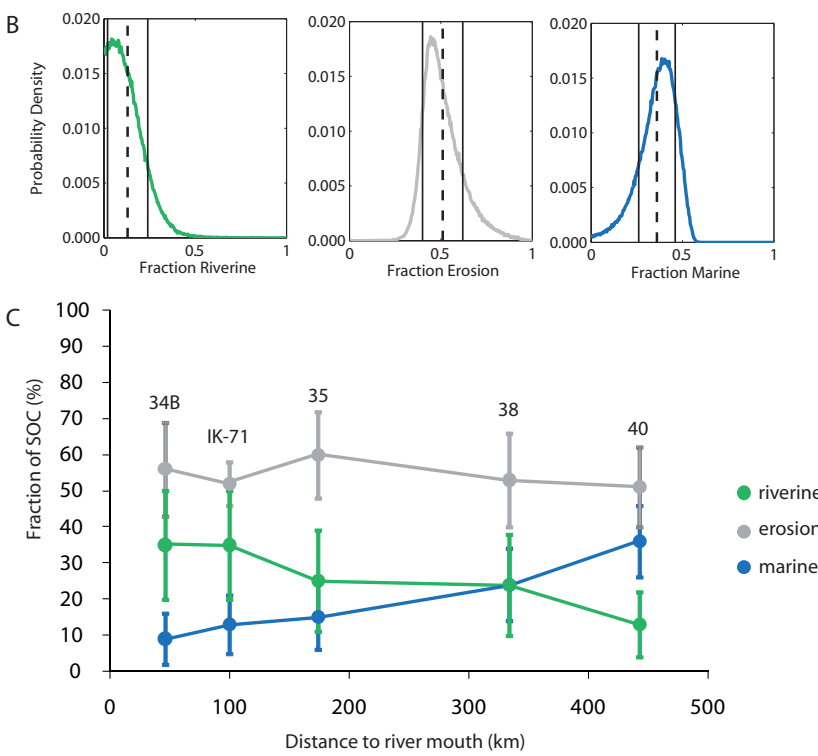

Fig. 3. Examples of Monte Carlo probability density functions for the fractions $f_{\text {riverine, }} f_{\text {erosion }}$ and $f_{\text {marine }}$ for YS-34B (a) and YS40 (b) with dashed vertical lines showing the mean values plus and minus one standard deviation (vertical lines). (c) Relative proportions (plus and minus one standard deviation from Monte Carlo simulations) of riverine (green), erosional (grey) and marine (blue) contributions to SOC in surface sediments along the Kolyma paleoriver transect.

found in the western ESS (up to $170^{\circ} \mathrm{E}$ ) and $28-70 \%$ in the eastern part. Our results are consistent with these latter estimates. The station IK-71 (100 km from the river mouth) from van Dongen et al. (2008a) shows relative fractions of $35 \%, 52 \%$ and $13 \%$ for riverine, erosion and marine sources (Fig. 3c), respectively, and are broadly consistent with our data. The carbon isotope signatures of surface POC $\left(\Delta^{14} \mathrm{C}\right.$ between -28 and $-75 \%$; $\sim 200-600{ }^{14} \mathrm{C}$ years; Fig. 2f, Table 2) cannot be used with the end-members in our mixing model. We suggest that surface POC during our sampling campaign is largely comprised of a mixture of riverine and marine OC, since erosion OC tends to settle close to land (Fig. 2e and Sánchez-García et al., 2010a). Thus, in terms of carbon burial processes, the surface sediments give a more integrated picture. Taken together, coastal erosion OC comprises the main fraction of SOC across the East Siberian shelf.
Table 3. Results from the Monte Carlo source apportionment calculations (given as mean \pm standard deviation) for the total OC in surface sediments along the Kolyma paleoriver transect (YS-34B to YS-40) and reference station IK-71 (van Dongen et al., 2008a). The end-members and the standard deviations used in the simulations are specified in the table footnotes, and further explained and referred to in the main text.

\begin{tabular}{llll}
\hline Station & \multicolumn{3}{c}{ Fractions } \\
\cline { 2 - 4 } & Riverine $^{\mathrm{a}}$ & Erosion $^{\mathrm{b}}$ & Marine $^{\mathrm{c}}$ \\
\hline YS-34B & $0.35 \pm 0.15$ & $0.56 \pm 0.13$ & $0.09 \pm 0.07$ \\
YS-36 & $0.25 \pm 0.14$ & $0.60 \pm 0.12$ & $0.15 \pm 0.09$ \\
YS-38 & $0.24 \pm 0.14$ & $0.53 \pm 0.13$ & $0.24 \pm 0.10$ \\
YS-40 & $0.13 \pm 0.09$ & $0.51 \pm 0.11$ & $0.36 \pm 0.10$ \\
IK-71 $^{\mathrm{d}}$ & $0.35 \pm 0.15$ & $0.52 \pm 0.14$ & $0.13 \pm 0.08$ \\
\hline
\end{tabular}

a End-member values used: $\delta^{13} \mathrm{C}-29.3 \%$ with standard deviation of $1.7 \%$; $\Delta{ }^{14} \mathrm{C}-296 \%$ with standard deviation of $68 \%$.

b End-member values used: $\delta^{13} \mathrm{C}-25.8 \%$ with standard deviation of $1.7 \%$ \% $\Delta^{14} \mathrm{C}-788 \%$ with standard deviation of $201 \%$ 。

$c$ End-member values used: $\delta^{13} \mathrm{C}-21 \%$ with standard deviation of $1 \%$ o $\Delta{ }^{14} \mathrm{C} 25 \%$ owith standard deviation of $25 \%$.

$\mathrm{d}$ Bulk sedimentary OC values used in calculations from van Dongen et al. (2008a) $\left(\Delta^{14} \mathrm{C}-503 \%\right.$ and $\delta^{13} \mathrm{C}-26.7 \%$ o).

\subsection{Cross-shelf redistribution processes}

The strong sedimentary imprint of coastally-eroded OC along the entire transect suggests transport in the benthic boundary layer and as ice-rafted debris, in combination with preferential degradation of riverine OC. Despite deposition of erosion-derived $\mathrm{OC}$, as coarse unsorted particles near the coastline (Fig. 2e), at least $50 \%$ of the SOC across this shelf is attributable to erosion, up to $500 \mathrm{~km}$ away from the coast. The southern ESS shelf with its shallow bottom topography is known to have a pronounced nepheloid layer due to wave and storm influence at least up to water depths of $25 \mathrm{~m}$ (Dudarev et al., 2006). This will allow for very slow but long-distance bottom transport, moving the terrestrial OC up to several hundreds of kilometers offshore. Such surface sediment winnowing-redeposition cycling is likely stochastic (e.g. affected by storms) and may yield sediment size/settling fractionation in the geochemical signal as has been detailed in other continental margin systems (e.g. Coppola et al., 2007). The input of terrestrial OC from sources other than rivers (i.e. coastal erosion; Fig. 1b) may be the most important source to the organic matter composition in the distinct nepheloid layer and in the surface sediments. We hypothesize that OC from coastal erosion (ESS input 2.2 Tg TOC/year; Stein and Macdonald, 2004) is associated with denser mineral particles than fluvial OC (ESS input 1.9 Tg TOC/year; Stein and Macdonald, 2004). Consequently, mineral-bound POC derived from erosion may have short initial residence times in the surface water and instead quickly settle to the sea floor. It is likely that a part of the yedoma OC is selectively preserved compared to riverine 
OC, due to mineral protection (e.g., Keil et al., 1994), which explains the decrease in the riverine $\mathrm{OC}$ fraction relative to the erosional OC fraction along the transect. Local, landbased studies of thawing yedoma show active and rapid respiration that clearly decreases over time (Dutta et al., 2006; Zimov et al., 2006). Accordingly, the eroded OC we trace in the coastal and shelf surface sediments may represent the remaining passive/recalcitrant fraction of yedoma OC that is washed into the ocean. Additionally, considerable proportions of land-derived OC (up to $6 \mathrm{Gg}$ POC/year for the ESS; Stein and Macdonald, 2004) may be transported offshore through incorporation in sea ice during spring flood and ice formation, a common process in shallow regions such as the East Siberian coastal area (Ogorodov, 2003; Supplement Fig. S1). Sea ice formation starts in early autumn, which coincides with the period of maximum coastal erosion due to extensive thermal degradation in combination with wave and storm action (Fig. 1b). Consequently, significant amounts of coastal OC can be incorporated in the ice and transported far out onto the shelf where it is released when the ice melts the subsequent summer. Overall, the dominant coastal erosion imprint in SOC across the East Siberian Shelf is likely due to a strong ongoing transport in the benthic boundary layer and in sea ice.

\subsection{Degradation and preservation of terrestrial organic matter}

Our measurements indicate that, in late summer, the terrestrial OC fraction in shelf surface water SPM was strongly degraded but young, while terrestrial OC in the underlying surface sediments was less degraded yet old. Long-chain $n$ alkanoic acids are inherently more susceptible to degradation than $n$-alkanes due to the presence of functional groups (e.g. Brassell et al., 1984). Ratios of long-chain $n$-alkanoic acids to long-chain $n$-alkanes are therefore used as an indicator of the extent of degradation of terrestrial OC (e.g. van Dongen 2008a, b; Vonk et al., 2008). During our sampling in late summer these ratios were higher in ESS surface sediments than in the water column (Fig. 4a). The single surface sediment described in van Dongen et al. (2008a) showed a lower ratio than most of our stations, but a similar value to nearby surface sediment station YS-36 (Fig. 4a). The further extent of degradation in the water column is contrary to what one may expect, and what has been found in other systems (e.g., Vonk et al., 2008) that there is a trend of increasing degradation along the route river - coastal surface water - sediment. An additional proxy for the extent of degradation is the odd-over-even predominance of HMW terrestrial compounds, demonstrated by the CPI (defined in Table 2). The significantly lower $n$-alkane CPIs in the water column compared to sediments confirm greater OC degradation in the surface water SPM (Fig. 4b). The CPI value for $n$-alkanes in a previous study (Fig. $4 \mathrm{~b}$; van Dongen et al., 2008a) is comparable to our values. Major terrestrial

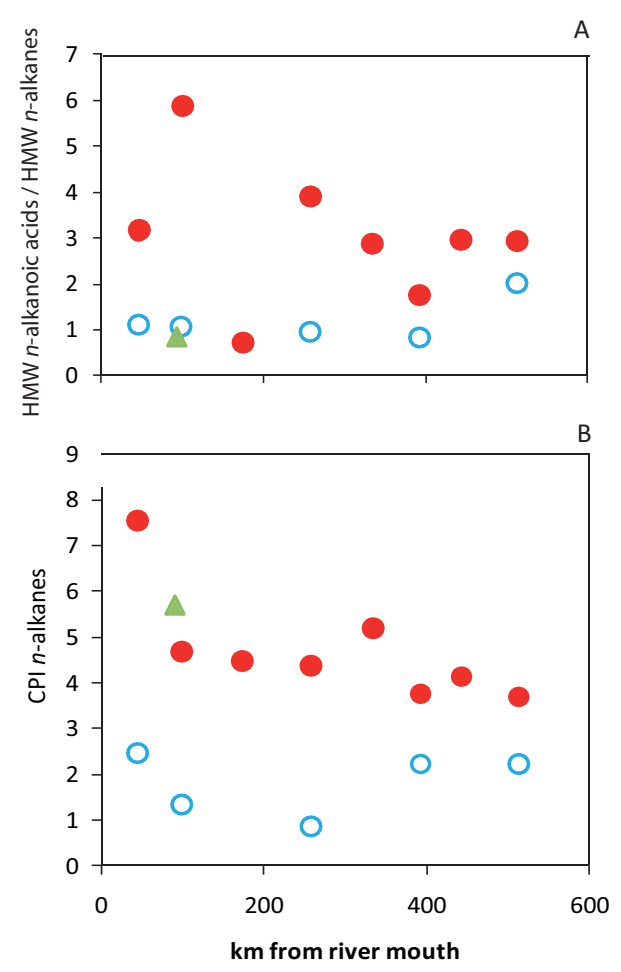

Fig. 4. Molecular indices of organic matter degradation in surface sediments (red closed symbols) and water column (blue open symbols) along the Kolyma paleoriver transect as shown by (a) HMW $n$-alkanoic acids/HMW $n$-alkanes, (b) CPI of $n$-alkanes. Green triangles represent the reference station IK-71 from van Dongen et al. (2008a).

contributions of rock erosion/weathering or oil could result in low $n$-alkane CPIs as has been observed in the Mackenzie River (Goñi et al., 2005). However, we can exclude these contributions due to the absence of an unresolved complex mixture (Gough et al., 1992) in our chromatograms, a low methylphenantrene:phenantrene ratio (Elmquist et al., 2008) in the surface sediment IK-71 (Fig. 1c), and the detection of fresh $\beta \beta$-hopanes in combination with the absence of $\alpha \beta$ and $\beta \alpha$-hopanes (Supplement Table S2; Peters and Moldovan, 1993). Surface water POC and surface sediment SOC showed a remarkable difference in bulk ${ }^{14} \mathrm{C}$ age; surface POC was $\sim 200-600{ }^{14} \mathrm{C}$ years old, while the underlying sediments exhibited bulk ages between $\sim 4500$ and $\sim 6500{ }^{14} \mathrm{C}$ years. However, since these measurements are performed on a bulk level, contributions of young marine OC may partially mask the old terrestrial ${ }^{14} \mathrm{C}$ signal. On the other hand, our end-member mixing model results only show limited imprints of marine OC (9 to $36 \%$, Sect. 3.3) in the underlying sediments.

We propose that the young and degraded terrestrial OC fraction in surface water SPM is derived from recent, readily degradable, surface soil OC and vegetation debris, emanating from the river as a buoyant surface plume that is dispersed 
over the continental shelf. As described earlier, the coastal erosion imprint in the water column is mostly confined to the near shore stations (Fig. 2e) due to preferential settling close to land. This would imply that the degraded OC signal we observe in the SPM originates from a terrestrial source other than coastal erosion, namely riverine input. Consistent with a recent study by Vonk et al. (2010), we hypothesize the riverine $\mathrm{OC}$ to originate in surface soils with mostly contemporary vegetation sources, giving rise to young ${ }^{14} \mathrm{C}$ ages. This fluvially delivered pool is highly bioavailable, as it exists as a light and buoyant suspension that is easily and extensively transported by horizontal dispersion (Gustafsson et al., 2000) along the Siberian coastal current that flows from west to east (Dudarev et al., 2006). Freshwater residence times in the ESS of several years (Schlosser et al., 1994a) will allow this terrestrial surface water pool, released mostly during spring flood in early June, to be subjected to active processing for at least a full summer period. Ongoing degradation of terrestrial OC in the ESS water column, inferred from measurements of excess $\mathrm{CO}_{2}$, is confirmed by recent studies (Semiletov et al., 2007; Anderson et al., 2009). Another source of degraded POC could be derived from cumulative thaw processes in late summer, remobilizing terrestrial OC from deeper active layers and thermally collapsing coasts. Several studies corroborate the release of older and more processed POC (Guo and Macdonald, 2006) and DOC (Neff et al., 2006; Raymond et al., 2007; Holmes et al., 2008) towards the end of the season.

We suggest that the old and less degraded terrestrial OC in the surface sediments originates from mineral soils. During fluvial and coastal transport, the OC-mineral associations of this OC pool serve as protection from degradation (Keil et al., 1994) and at the same time ballast the material, inducing rapid settling (Armstrong et al., 2002; Gustafsson et al., 2006; Vonk et al., 2010). The landmass adjacent to our study region contains two dominant sources of mineral-bound OC: coastal yedoma and frozen mineral soils (turbels). Pleistocene yedoma with high mineral $\mathrm{C}$ contents ( $\sim 80 \%$; Dutta et al., 2006$)$ is released through coastal erosion. Further inland, deeper mineral soils can reach ages from several millennia to millions of years (MacDonald et al., 2006; Zimov et al., 2006), as this region was free of landscape-scouring glaciers during cold and dry glacial periods. Upon thawing, these soil OC pools are fluvially remobilized through groundwater flow and thermokarst processes, and transported to the coastal system. Strong ongoing climate warming in the East Siberian Arctic (RichterMenge et al., 2006) may mobilize and increase the fluvial and coastal delivery of these old and recalcitrant mineral OC pools through development of shallow groundwater flow paths in regions of thawing permafrost (Bense et al., 2009; Frey and McClelland, 2009), and enhanced thermal degradation of the coastline (Stein and Macdonald, 2004). This study confirms the previous finding of Vonk et al. (2010) that different (sub-)Arctic soil OC pools exhibit considerably different vulnerabilities toward degradation, and are subject to different fates upon discharge to the coastal environment.

\section{Conclusions}

Surface waters and bottom sediments along a $500 \mathrm{~km}$ Kolyma river-mouth to mid-shelf transect in the ESS show a clear imprint of terrestrial OC from higher plants. This imprint is particularly prominent in the surface sediments. A three end-member isotopic mixing model for SOC revealed that the proportion of fluvially-derived $\mathrm{OC}$ decreased with offshore distance (35-13\%), whereas the proportion of OC derived from coastal erosion was substantial and relatively constant (51-60\%). We attribute this dispersal of erosion OC to strong benthic boundary layer transport and/or offshore transport through ice-rafting, in combination with selective preservation of yedoma-erosion OC relative to riverine OC. Molecular and isotopic differences between surface water SPM and bottom sediments suggest the delivery of different soil OC pools to the ESS. Terrestrial OC in surface water SPM originates largely from contemporary vegetation and surface soil OC that is extensively degraded during fluvial transport and dispersal in shelf waters as a buoyant plume. The underlying surface sediments showed an imprint of old and less degraded terrestrial OC, suggesting this material primarily originates in mineral soils. Mineral-OC associations in these soils protect organic matter from extensive degradation and provide ballast to promote rapid settling in the near-shore environment. Mineral-bound OC pools are abundant in Pleistocene yedoma and permafrost soils in the Kolyma watershed, and are released to the coastal environment through coastal erosion and rivers. These findings add to recent studies that mineral-bound OC from coastal yedoma and deeper mineral soils in the Arctic is more efficiently preserved and buried in coastal sediments than contemporary OC pools from surface soils. This implies that the coastal fate of a key fraction of thaw-released permafrost soil OC is reburial on the shelves instead of degradation and associated emission as greenhouse gases into the atmosphere.

\section{Supplementary material related to this article is available online at: http://www.biogeosciences.net/7/3153/2010/ bg-7-3153-2010-supplement.pdf.}

Acknowledgements. We wish to thank many colleagues of the International Siberian Shelf Study 2008 (ISSS-08): Martin Kruså and Bart van Dongen for massive numbers of high-volume GF/F filtrations, Göran Björk for the salinity and depth data, Vladimir Mordukhovich for help with sediment sampling and many other colleagues onboard the ISSS-08 expedition for laboratory and field assistance. The ISSS-08 program was supported by the Knut and Alice Wallenberg Foundation, Headquarters of the Far Eastern Branch of the Russian Academy of Sciences, the 
Swedish Research Council (VR Contract No. 621-2004-4039 and 621-2007-4631), the US National Oceanic and Atmospheric Administration (Siberian Shelf Study), the Russian Foundation of Basic Research (08-05-13572, 08-05-00191-a, and 07-05-00050a), the Swedish Polar Research Secretariat, the Arctic Co-Op Program of the Nordic Council of Ministers (331080-70219) and the National Science Foundation (OPP ARC 0909546). Ö. G. also acknowledges financial support as an Academy Research Fellow from the Swedish Royal Academy of Sciences, L. S. a Marie Curie grant (contract no. PIEF-GA-2008-220424), T. E. an NSF grant (ARC-0909377) and A. A. support from the Knut and Alice Wallenberg Foundation.

Edited by: L. Anderson

\section{References}

Anisimov, O. and Reneva, S.: Permafrost and changing climate: the Russian perspective, Ambio, 35(4), 169-175, 2006.

Anderson, L. G., Jutterström, S., Hjalmarsson, S., Wåhlström, I., and Semiletov, I.: Out-gassing of $\mathrm{CO}_{2}$ from Siberian Shelf seas by terrestrial organic matter decomposition, Geophys. Res. Lett., 36, L20601, doi:10.1029/2009/GL040046, 2009.

Armstrong, R. A., Lee, C., Hedges, J. I., Honjo, S., and Wakeham, S. G.: A new, mechanistic model for organic carbon fluxes in the ocean: based on the quantitative association of POC with ballast minerals, Deep-Sea Res. Pt. II, 49, 219-236, 2002.

Bense, V. F., Ferguson, G., and Kooi, H.: Evolution of shallow groundwater flow systems in areas of degrading permafrost, Geophys. Res. Lett., 36, L22401, doi:10.1029/2009GL039225, 2009.

Brassell, S. C., McEvoy, J., Hoffmann, C. F., Lamb, N. A., Peakman, T. M., and Maxwell, J. R.: Isomerisation, rearrangement and aromatisation of steroids in distinguishing early stages of diagenesis, Org. Geochem., 6, 11-23, 1984.

Chudinova, S. M., Frauenfeld, O. W., Barry, R. G., Zhang, T. J., and Sorokovikov, V. A.: Relationship between air and soil temperature trends and periodicities in the permafrost regions of Russia, J. Geophys. Res-Earth, 111, 1-15, 2006.

Cooper, L. W., McClelland, J. W., Holmes, R. M., Raymond, P. A., Gibson, J. J., Guay, C. K., and Peterson, B. J.: Flow-weighted values of runoff tracers (delta 18O, DOC, Ba, alkalinity) from the six largest Arctic rivers, Geophys. Res. Lett., 35, L18606, doi:10.1029/2008GL035007, 2008.

Coppola, L., Gustafsson, Ö., Andersson, P., Eglinton, T. I., Uchida, M., and Dickens, A. F.: The importance of ultrafine particles as a control on the distribution of organic carbon in Washington Margin and Cascadia Basin sediments, Chem. Geol., 243, 142156, 2007.

Dudarev, O. V., Semiletov, I. P., Charkin, A. N., and Botsul, A. I.: Deposition settings on the continental shelf of the East Siberian Sea, Dokl. Earth Sci., 409(6), 822-827, 2006.

Dutta, K., Schuur, E. A. G., Neff, J. C., and Zimov, S. A.: Potential carbon release from permafrost soils of Northeastern Siberia, Glob. Change Biol., 12, 2336-2351, 2006.

Eglinton, G. and Hamilton, R. J.: Leaf epicuticular waxes, Science, 156, 1322-1335, 1967.

Elmquist, M., Semiletov, I., Guo, L., and Gustafsson, Ö: PanArctic patterns in black carbon sources and fluvial discharges deduced from radiocarbon and PAH source apportionment mark- ers in estuarine surface sediments, Global Biogeochem. Cy., 22, GB2018, doi:10.1029/2007GB002994, 2008.

Frey, K. E. and McClelland, J. W.: Impacts of permafrost degradation on arctic river biogeochemistry, Hydrol. Process., 23, 169182, doi:10.1002/hyp.7196, 2009.

Goericke, R. and Fry, B.: Variations of marine plankton $\delta^{13} \mathrm{C}$ with latitude, temperature, and dissolved $\mathrm{CO}_{2}$ in the world ocean, Global Biogeochem. Cy., 8, 85-90, 1994.

Goñi, M. A., Yunker, M. B., Macdonald, R. W., and Eglinton, T. I.: The supply and preservation of ancient and modern components of organic carbon in the Canadian Beaufort Shelf of the Arctic Ocean, Mar. Chem., 93, 53-73, 2005.

Gough, M. A., Rhead, M. M., and Rowland, S. J.: Biodegradation studies of unresolved complex-mixtures of hydrocarbons: Model UCM hydrocarbons and the aliphatic ICM, Org. Geochem., 18, 17-22, 1992.

Gruber, N., Friedlingstein, P., Field, C. B., Valentini, R., Heimann, M., Richey, C. B., Romero-Lankao, P., Schulze, D., and Chen, C.-T. A.: The vulnerability of the carbon cycle in the 21 st century: An assessment of carbon-climate-human interactions, in: The Global Carbon Cycle: Integrating Humans, Climate, and the Natural World, edited by: Field, C. B. and Raupach, M. R., Island Press, Washington, D.C., 45-76, 2004.

Guo, L. and Macdonald, R. W.: Source and transport of terrigenous organic matter in the upper Yukon River: Evidence from isotopic $\left(\delta^{13} \mathrm{C}, \Delta^{14} \mathrm{C}\right.$, and $\left.\delta^{15} \mathrm{~N}\right)$ composition of dissolved, colloidal, and particulate phases, Global Biogeochem. Cy., 20, GB2011, doi:10.1029/2005GB002593, 2006.

Guo, L., Ping, C.-L., and Macdonald, R. W.: Mobilization pathways of organic carbon from permafrost to arctic rivers in a changing climate, Geophys. Res. Lett., 34, L13603, doi:10.1029/2007GL030689, 2007.

Guo, L. D., Semiletov, I., Gustafsson, Ö., Ingri, J., Andersson, P., Dudarev, O., and White, D.: Characterization of Siberian Arctic coastal sediments: Implications for terrestrial organic carbon export, Global Biogeochem. Cy., 18, GB1036, doi:10.1029/2003GB992087, 2004.

Gustafsson, Ö., Andersson, P., Axelman, J., Bucheli, T. D., Kömp, P., McLachlan, M. S., Sobek, A., Thörngren, J.-O.: Observations of the PCB distribution within and in-between ice, snow, ice-rafted debris, ice-interstitial water, and seawater in the Barents Sea marginal ice zone and the North Pole area, Sci. Total Environ., 342, 261-279, 2005.

Gustafsson, Ö., Larsson, J., Andersson, P., and Ingri, I.: The $\mathrm{POC} /{ }^{234} \mathrm{Th}$ ratio of settling particles isolated using split flowthin cell fractionation (SPLITT), Mar. Chem., 100, 314-322, 2006.

Gustafsson, Ö., Widerlund, A., Andersson, P. S., Ingri, J., Roos, P., and Ledin, A.: Colloid dynamics and transport of major elements through a boreal river - brackish bay mixing zone, Mar. Chem., 71, 1-21, 2000.

Hedges, J. I., Keil, R. G., and Benner, R.: What happens to terrestrial organic matter in the ocean?, Org. Geochem., 27, 195-212, 1997.

Hedges, J. I. and Oades, J. M.: Comparative organic geochemistries of soils and marine sediments, Org. Geochem., 27, 319-361, 1997.

Holmes, R. M., McClelland, J. W., Peterson, B. J., Shiklomanov, I. A., Shiklomanov, A. I., Zhulidov, A. V., Gordeev, V. V., and 
Bobrovitskaya, N. N.: A circumpolar perspective on fluvial sediment flux to the Arctic Ocean, Global Biogeochem. Cy., 16(4), 1098, doi:10.10292001GB001849, 2002.

Holmes, R. M., McClelland, J. W., Raymond, P. A., Frazer, B. B., Peterson, B. J., and Stieglitz, M.: Lability of DOC transported by Alaskan rivers to the Arctic Ocean, Geophys. Res. Lett., 35, L03402, doi:10.1029/2007GL032837, 2008.

Huh, Y., Panteleyev, G., Babich, D., Zaitsev, A., and Edmond, J. M.: The fluvial geochemistry of the rivers of Eastern Siberia: II. Tributaries of the Lena, Omoloy, Yana, Indigirka, Kolyma, and Anadyr draining the collisional/accretionary zone of the Verkhoyansk and Cherskiy ranges, Geochim. Cosmochim. Ac., 62(12), 2053-2075, 1998.

Keil, R. G., Montlucon, D. B., Prahl, F. G., and Hedges, J. I.: Sorptive preservation of labile organic matter in marine sediment, Nature, 370, 549-552, doi:10.1038/370549a0, 1994.

Key, R. M., Kozyr, A., Sabine, C. L., Lee, K., Wanninkhof, R., Bullister, J. L., Feely, R. A., Millero, F. J. Mordy, C., and Peng, T.-H.: A global ocean carbon climatology: Results from Global Data Analysis Project (GLODAP), Global Biogeochem. Cy., 18, GB4031, doi:10.1029/2004GB002247, 2004.

Khvorostyanov, D. V., Ciais, P., Krinner, G., and Zimov, S. A.: Vulnerability of East Siberia's frozen carbon stores to future warming, Geophys. Res. Lett., 35, L10703, doi:10.1029/2008GL033639, 2008.

Kremenetski, K. V., Velichko, A. A., Borisova, O. K., MacDonald, G. M., Smith, L. C., Frey, K. E., and Orlova, L. A.: Peatlands of the western Siberian lowlands: Current knowledge on zonation, carbon content and Late Quaternary history, Quat. Sci. Rev., 22, 703-723, 2003

MacDonald, G. M., Beilman, D. W., Kremenetski, K. V., Sheng, Y., Smith, L. C., and Velichko, A. A.: Rapid early development of circumarctic peatlands and atmospheric $\mathrm{CH}_{4}$ and $\mathrm{CO}_{2}$ variations, Science, 314, 285-288, doi:10.1126/science.1131722, 2006.

Majhi, I. and Yang, D.: Streamflow Characteristics and Changes in Kolyma Basin in Siberia, J. Hydrometeorol., 9, 267-279, doi: 10.1175/2007jhm845.1, 2008.

McClelland, J. W., Holmes, R. M., Peterson, B. J., Amon, R., Brabets, T., Cooper, L., Gibson, J., Gordeev, V. V., Guay, C., Milburn, D., Staples, R., Raymond, P. A., Shiklomanov, I., Striegl, R., Zhulidov., A., Gurtovaya, T., and Zimov, S.: Development of a pan-Arctic database for river chemistry, Eos Trans. AGU, 89(24), 217-218, doi:10.1029/2008EO240001, 2008.

McGuire, A. D., Anderson, L. G., Christensen, T. R., Dallimore, S., Guo, L., Hayes, D. J., Heimann, M., Lorenson, T. D., Macdonald, R. W., and Roulet, N.: Sensitivity of the carbon cycle in the Arctic to climate change, Ecol. Monogr., 79, 523-555, 2009.

Meyers, P. A.: Organic geochemical proxies of paleoceanographic, paleolimnologic, and paleoclimatic processes, Org. Geochem., 27, 213-250, 1997.

Neff, J. C., Finlay, J. C., Zimov, S. A., Davydov, S. P., Carrasco, J. J., Schuur, E. A. G., and Davydova, A. I.: Seasonal changes in the age and structure of dissolved organic carbon in Siberian rivers and streams, Geophys. Res. Lett., 33, L23401, doi:10.1029/2006GL028222, 2006.

Ogodorov, S. A.: The role of sea ice in the coastal zone dynamics of the Arctic Seas, Water Resour., 30, 509-518, 2003.

Ostlund, H. G., Possnert, G., and Swift, J. H.: Ventilation rate of the deep Arctic Ocean from carbon 14 data, J. Geophys. Res., 92, 3769-3777, 1987.

Overduin, P. P., Hubberten, H. W., Rachold, V., Romanovskii, N., Grigoriev, M., and Kasymskaya, M.: The evolution and degradation of coastal and offshore permafrost in the Laptev and East Siberian Seas during the last climatic cycle, Geol. S. Am. S., 426, 97-110, 2007.

Peters, K. E. and Moldowan, J. M.: The Biomarker Guide, Interpreting Molecular Fossils in Petroleum and Ancient Sediments, Prentice-Hall, Englewood Cliffs, NJ, 675-694, 1993.

Peterson, B. J., Holmes, R. M., McClelland, J. W., Vorosmarty, C. J., Lammers, R. B., Shiklomanov, A. I., Shiklomanov, I. A., and Rahmstorf, S.: Increasing river discharge to the Arctic Ocean, Science, 298, 2171-2173, 2002.

Peterson, B. J., McClelland, J., Curry, R., Holmes, R. M., Walsh, J. E., and Aagaard, K.: Trajectory shifts in the Arctic and subarctic freshwater cycle, Science, 313, 1061-1066, 2006.

Rachold, V., Grigoriev, M. N., Are, F. E., Solomon, S., Reimnitz, E., Kassens, H., and Antonow, M.: Coastal erosion vs. riverine sediment discharge in the Arctic shelf seas, Int. J. Earth Sci., 89, 450-460, 2000.

Rau, G. H., Sweeny, R. E., and Kaplan, I. R.: Plankton 13C: 12C ratio changes with latitude: differences between northern and southern oceans, Deep-Sea Res., 29, 1035-1039, 1982.

Raymond, P. A., McClelland, J. W., Holmes, R. M., Zhulidov, A. V., Mull, K., Peterson, B. J., Striegl, R. G., Aiken, G. R., and Gurtovaya, T. Y.: Flux and age of dissolved organic carbon exported to the Arctic Ocean: A carbon isotopic study of the five largest arctic rivers, Global Biogeochem. Cy., 21, GB4011, doi:10.1029/2007GB002934, 2007.

Richter-Menge, J., Overland, J., Proshutinsky, A., Romanovsky, V., Bengtsson, L., Brigham, L., Dyurgerov, M., Gascard, J. C., Gerland, S., Graversen, R., Haas, C., Karcher, M., Kuhry, P., Maslanik, J., Melling, H., Maslowski, W., Morison, J., Perovich, D., Przybylak, R., Rachold, V., Rigor, I., Shiklomanov, A., Stroeve, J., Walker, D., and Walsh, J.: State of the Arctic Report, NOAA OAR Special Report, NOAA/OAR/PMEL, Seattle, WA, 36 pp., 2006.

Rieley, G., Collier, R. J., Jones, D. M., and Eglinton, G.: Biogeochemistry of Ellesmere Lake, UK I. Source correlation of leaf wax inputs to the sedimentary lipid record, Org. Geochem., 17, 901-912, 1991.

Romanovsky, N. N.: Fundamentals of the Cryogenesis of the Lithosphere, University Press, Moscow, 1-336, 1993 (in Russian).

Romanovsky, V. E., Sazonova, T. S. Balobaev, V. T., Shender, N. I., and Sergueev, D. O.: Past and recent changes in air and permafrost temperatures in eastern Siberia, Global Planet. Change, 56, 399-413, 2007.

Russell, J. M. and Werne, J. P.: The use of solid phase extraction columns in fatty acid purification, Org. Geochem., 38, 48-51, 2007.

Sánchez-García, L., Alling, V., Pugach, S., Vonk, J., van Dongen, B., Humborg, C., Dudarev, O., Semiletov, I., and Gustafsson, Ö.: Inventories and behavior of particulate organic carbon in the Laptev and East Siberian Seas, Global Biogeochem. Cy., in review, 2010a.

Sánchez-García, L., Vonk, J., Charkin, A., Kosmach, D., Dudarev, O., Semiletov, I. P., and Gustafsson, Ö.: Remobilization and degradation of Muostakh Island (Laptev Sea) as part of the col- 
lapsing Arctic coastal ice complex, in preparation, 2010b.

Savelieva, N. I., Semiletov, I. P., Vasilevskaya, L. N., and Pugach, S. P.: A climate shift in seasonal values of meteorological and hydrological parameters for Northeastern Asia, Prog. Oceanogr., 47, 279-297, 2000.

Sazonova, T. S., Romanovsky, V. E., Walsh, J. E., and Sergueev, D. O.: Permafrost dynamics in the 20th and 21st centuries along the East Siberian transect, J. Geophys. Res.-Atmos., 109, D01108, doi:10.1029/2003JD003680, 2004.

Schirrmeister, L., Siegert, C., Kuznetsova, T., Kuzmina, S., Andreev, A., Kienast, F., Meyer, H., and Bobrov, A.: Paleoenvironmental and paleoclimatic records from permafrost deposits in the Arctic region of Northern Siberia, Quatern. Int., 89, 97-118, 2002.

Schlosser, P., Bauch, D., Fairbanks, R., and Bonisch, G.: Arctic river-runoff - mean residence time on the shelves and in the halocline, Deep-Sea Res. Pt. I, 41, 1053-1068, 1994a.

Schlosser, P., Kromer, B., Ostlund, G., Ekwurzel, B., Bonisch, G., Loosli, H. H., and Purtschert, R.: On the ${ }^{14} \mathrm{C}$ and ${ }^{39} \mathrm{Ar}$ distribution in the Central Arctic Ocean: Implications for deep water formation, Radiocarbon, 36, 327-343, 1994b.

Schuur, E. A. G., Bockheim, J., Canadell, J. G., Euskirchen, E., Field, C. B., Goryachkin, S. V., Hagemann, S., Kuhry, P., Lafleur, P. M., Lee, H., Mazhitova, G., Nelson, F. E., Rinke, A., Romanovsky, V. E., Shiklomanov, N., Tarnocai, C., Venevsky, S., Vogel, J. G., and Zimov, S. A.: Vulnerability of permafrost carbon to climate change: implications for the global carbon cycle, Bioscience, 58, 701-714, doi:10.1641/B580807, 2008.

Semiletov, I. P.: Destruction of the coastal permafrost as an important factor in biogeochemistry of the Arctic shelf waters, Dokl. Earth Sci., 368, 679-682, 1999a.

Semiletov, I. P.: Aquatic sources and sinks of $\mathrm{CO}_{2}$ and $\mathrm{CH}_{4}$ in the polar regions, J. Atmos. Sci., 56, 286-306, 1999b.

Semiletov, I., Dudarev, O., Luchin, V., Charkin, A., Shin, K.-H., and Tanaka, N.: The East Siberian Sea as a transition zone between Pacific-derived waters and Arctic shelf waters, Geophys. Res. Lett., 32, L10614, doi:10.1029/2005GL022490, 2005.

Semiletov, I. P., Pipko, I. I., Repina, I., and Shakhova, N. E.: Carbonate chemistry dynamics and carbon dioxide fluxes across the atmosphere-ice-water interfaces in the Arctic Ocean: Pacific sector of the Arctic, J. Marine Syst., 66, 204-206, doi:10.1016/j.jmarsys.2006.05.012, 2007.

Sobek, A., Gustafsson, Ö., Hajdu, S., and Larsson, U.: Particlewater partitioning of PCBs in the photic zone: A 25-month study in the open Baltic Sea, Environ. Sci. Technol., 38, 1375-1382, 2004.

Stein, R. and Macdonald, R. W. (Eds.): The organic carbon cycle in the Arctic Ocean, Springer, Berlin, 2004.

Tarnocai, C., Canadell, J. G., Schuur, E. A. G., Kuhry, P., Mazhitova, G., and Zimov, S.: Soil organic carbon pools in the northern circumpolar permafrost region, Global Biogeochem. Cy., 23, GB2023, doi:10.1029/2008GB003327, 2009.
Uhlîrová, E., Šantråčková, H., and Davidov, S. P.: Quality and potential biodegradability of soil organic matter preserved in permafrost of Siberian tussock tundra, Soil Biol., 39, 1978-1989, 2007.

Van Dongen, B. E., Semiletov, I., Weijers, J. W. H., and Gustafsson, Ö.: Contrasting lipid biomarker composition of terrestrial organic matter exported from across the Eurasian Arctic by the five Great Russian Arctic Rivers, Global Biogeochem. Cy., 22, GB1011, doi:10.1029/2007GB002974, 2008a.

Van Dongen, B. E., Zencak, Z., and Gustafsson, Ö.: Differential transport and degradation of bulk organic carbon and specific terrestrial biomarkers in the surface waters of a sub-arctic brackish bay mixing zone, Mar. Chem., 112(3-4), 203-214, doi:10.1016/j.marchem.2008.08.002, 2008b.

Vetrov, A. A., Semiletov, I. P., Dudarev, O., Peresypkin, V. I., and Charkin, A. N.: Composition and genesis of the organic matter in the bottom sediments on the East Siberian Sea, Geochem. Int., 46, 156-167, 2008.

Viscosi-Shirley, C., Mammone, K. Pisias, N., and Dymond, J.: Clay mineralogy and multi-element chemistry of surface sediments on the Siberian-Arctic shelf: implications for sediment provenance and grain size sorting, Cont. Shelf Res., 23, 1175-1200, 2003.

Vonk, J. E., van Dongen, B. E., and Gustafsson, Ö.: Lipid biomarker investigation of the origin and diagenetic state of sub-arctic terrestrial organic matter presently exported into the northern Bothnian Bay, Mar. Chem., 112, 1-10, 2008.

Vonk, J. E., van Dongen, B. E., and Gustafsson, Ö.: Selective preservation of old organic carbon fluvially released from sub-arctic soils, Geophys. Res. Lett., 37, L11605, doi:10.1029/2010GL042909, 2010.

Vonk, J. E. and Gustafsson, Ö.: Calibrating n-alkane Sphagnum proxies in sub-Arctic Scandinavia, Org. Geochem., 40, 10851090, doi:10.1016/j.orggeochem.2009.07.002, 2009.

Woo, M. K., Thorne, R., Szeto, K., and Yang, D.: Streamflow hydrology in the boreal region under the influences of climate and human interference, Phil. Trans. R. Soc. B, 363, 2251-2260, doi:10.1098/rstb.2007.2197, 2008.

Yunker, M. B., Belicka, L. L., Harvey, H. R., and Macdonald, R. W.: Tracing the inputs and fate of marine and terrigenous organic matter in Arctic Ocean sediments: A multivariate analysis of lipid biomarkers, Deep-Sea Res. Pt. II, 52, 3478-3508, 2005.

Yunker, M. B., Macdonald, R. W., Veltkamp, D. J., and Cretney, W. J.: Terrestrial and marine biomarkers in a seasonally ice-covered Arctic estuary - integration of multivariate and biomarker approaches, Mar. Chem., 49, 1-50, 1995.

Zimov, S. A., Davydov, S. P., Zimova, G. M., Davydova, A. I., Schuur, E. A. G., Dutta, K., and Chapin III, F. S.: Permafrost carbon: Stock and decomposability of a globally significant carbon pool, Geophys. Res. Lett., 33, L20502, doi:10.1029/2006GL027484, 2006. 